IZA DP No. 9436

The Association between Immigration and Labor Market Outcomes in the United States

Gaetano Basso

Giovanni Peri

October 2015 


\title{
The Association between Immigration and Labor Market Outcomes in the United States
}

\author{
Gaetano Basso \\ University of California, Davis \\ Giovanni Peri \\ University of California, Davis \\ and IZA
}

\section{Discussion Paper No. 9436 \\ October 2015}

\author{
IZA \\ P.O. Box 7240 \\ 53072 Bonn \\ Germany \\ Phone: +49-228-3894-0 \\ Fax: +49-228-3894-180 \\ E-mail: iza@iza.org
}

\begin{abstract}
Any opinions expressed here are those of the author(s) and not those of IZA. Research published in this series may include views on policy, but the institute itself takes no institutional policy positions. The IZA research network is committed to the IZA Guiding Principles of Research Integrity.

The Institute for the Study of Labor (IZA) in Bonn is a local and virtual international research center and a place of communication between science, politics and business. IZA is an independent nonprofit organization supported by Deutsche Post Foundation. The center is associated with the University of Bonn and offers a stimulating research environment through its international network, workshops and conferences, data service, project support, research visits and doctoral program. IZA engages in (i) original and internationally competitive research in all fields of labor economics, (ii) development of policy concepts, and (iii) dissemination of research results and concepts to the interested public.
\end{abstract}

IZA Discussion Papers often represent preliminary work and are circulated to encourage discussion. Citation of such a paper should account for its provisional character. A revised version may be available directly from the author. 


\section{ABSTRACT \\ The Association between Immigration and Labor Market Outcomes in the United States}

In this paper we present important correlations between immigration and labor market outcomes of native workers in the US. We use data on local labor markets, states and regions from the Census and American Community Survey over the period 1970-2010. We first look at simple correlations and then we use regression analysis with an increasing number of controls for observed and unobserved factors. We review the potential methods to separate the part of this correlation that captures the causal link from immigrants to native labor outcomes and we show estimates obtained with 2SLS method using the popular shiftshare instrument. One fact emerging from all the specifications is that the net growth of immigrant labor has a zero to positive correlation with changes in native wages and native employment, in aggregate and by skill group. We briefly review the literature on the channels and the mechanisms that allow local economies to absorb immigrants with no negative (and possibly positive) impact on the labor demand for natives.

\section{NON-TECHNICAL SUMMARY}

We show that correlation of immigration and wages/employment of US natives were positive or null at all levels of geography and in aggregate as well as for skill groups, in the period 1970-2010. This suggests that we need to analyze theories of how local economies absorb immigrants without negative effects on native labor demand.

JEL Classification: J21, J31, J61

Keywords: immigration, employment, wages, labor markets

Corresponding author:

Giovanni Peri

University of California, Davis

One Shields Avenue

Davis, CA 95616

USA

E-mail: gperi@ucdavis.edu 


\section{Introduction}

The labor market and, more generally, the economic impact of immigrants in the United States are highly researched topics. Several influential articles have been written since the 1980's on immigration and native wages and employment (Grossman 1982, Card 1990, Borjas, Freeman and Katz 1997, Friedberg and Hunt 1995, Friedberg 2001). There has been some disagreement on whether the association between immigrant and wages is negative, positive or null (e.g. Borjas 2003, Card 2009 and Ottaviano and Peri 2012). The economics of how immigrants affect native wages and employment can be framed in a very simple labor demand and labor supply model for homogeneous workers. Such a basic canonical model with a negatively sloped labor demand curve implies that in the short run an increase in supply due to immigration, keeping everything else constant, produces a decline in wage and/or in employment for native workers. In the long run as capital adjusts this model predicts no effect on native wages and employment.

There are many reasons, however, to believe that the simple canonical model described above is a gross oversimplification as it omits aspects that are crucial for the issue at hand. Immigrants are not homogeneous to natives, technology and capital adjusts in response to labor, firms create jobs in response to incentives, there are complementarity across different workers, more workers allow for specialization and division of labor that could enhance efficiency, and so on. All these factors imply that the marginal product of native labor may change when the supply of immigrant changes, and it may change in a direction that offsets or overturns the negative effects implied by the canonical model. In other words, the change in supply of immigrant workers may correspond to an ambiguous change in the demand for native workers. It could be positive or negative depending on the relative strength of competition and complementarity/productivity effects.

A second issue limiting the relevance of the "supply shift with-everything-else-constant" paradigm is that we rarely observe "sudden and short lived" changes in immigration rates. The usual scenario is one in which a slow but persistent increase in immigration rates shapes, over decades, the labor markets of the receiving countries. In this context several adjustments take place concurrently with the immigrant inflow. Even the more remarkable examples of immigration "booms" entailed net inflows only around 0.5 to $1 \%$ of the population each year. One of these immigration episodes took place in Israel during the period 1990-2000, due to Jewish immigrants from the ex-Soviet Union: in that episode, the share of foreign-born increased by 10 percentage points of the population in a decade. 
In another episode, from 1995 to 2008, the share of foreign-born in Spain increased by 11 percentage points due to immigration. By comparison, the period of largest US immigration, namely the years 1990-2010, experienced an increase in the share of foreign-born by 5 percentage points, hence an average of 0.25 percentage of the population each year. Most of the other countries have had much smaller yearly rates for a period of few decades. ${ }^{1}$ It is more useful, therefore, to think of a framework in which the inflow of immigrants changes the long run equilibrium in the labor markets over decades. As both labor demand and labor supply change in the long-run and immigration may affect both dynamics, there is no clear prediction of the sign of the effects.

For these reasons it is useful to go to the data to learn about the long-run correlations between changes in immigrant population and native wages and employment without a pre-conceived expectation about their sign. We analyze these correlations for the US over the period 1970-2010, considering several different dimensions pertaining geographical areas and skill groups in Section 2 of this paper.

There are reasons to think that in the long run the correlation immigrant-native demand can be negative if forces of competition, crowding and decreasing returns prevail. But there are as many reasons to think that a positive correlation will prevail if agglomeration economies, labor and capital complementarity, specialization and skill externalities prevail. By analyzing the long-run correlations between these variables we obtain a picture of their joint movements in equilibrium. While correlations "per se" cannot reveal what is their driving force, and hence they cannot identify the causal effects of immigration, they may suggest some scenarios and rule out others, especially if they are consistent across decades and across geographical units. Moreover, other important long-run forces driving changes in the labor market, such as technology, change in demographic groups and changes in schooling attainments are, at least in part, observable. Thus, we can absorb their variation and only distill the correlation that survives such controls to better approximate the causal link between immigrants and native wages.

With these caveats in mind we will estimate a series of basic regressions that progressively absorb the variation of confounding (observable and unobservable) factors so as to isolate a partial correlation between immigrant supply and native wages and employment. Overall we find correlations that are positive or not significantly different from 0 and rather stable across different periods, geographical units and specifications. These

\footnotetext{
${ }^{1}$ There have been some episodes of large refugee migrations in a short amount of time such as the Bosnians in the mid 1990's, but their flows were not too large.
} 
correlations reveal that, unless specific unobserved factors systematically offset the crowding and competition effects by immigrants, the identified correlations do not support the existence of negative and significant effects of immigration on native labor demand. We present this analysis in Section 3.

Even the more sophisticated regression analysis, however, cannot really ensure that we are fully identifying causation from immigration to native labor demand. While the positive correlations are suggestive, and the robustness to controls is encouraging, we need to have a more systematic way to separate the causal link between exogenous changes in immigrant labor supply and native wages and employment. In Section 4 we discuss the frequently used method of instrumental variables estimation, and the popular instruments in this context, defined as "shift-share" (or "enclave-based"). That method aims at isolating supply-driven changes in immigrants. We apply this instrumental variable technique to our regression analysis and observe only a small change in the point estimates of the correlation between immigrants and average native wages. The precision of the estimates, however, deteriorates significantly. We also discuss in that section more recent and promising methods that leverage policy changes and their variation across regions or the discontinuity over time of migratory flows as source of exogenous variation of immigrant labor supply. While those methods are interesting and promising, it is hard to find policy changes and push-episodes for all countries and years. Hence the shift-share instrument may still have an important role and it needs to be constructed accurately, paying attention to important details.

Finally, acknowledging that most of the simple and sophisticated correlations and 2SLS correlations between immigrant labor supply and native wages are positive or null, in Section 5 we identify some recent papers that analyze channels and mechanisms allowing absorption of immigrant labor with positive effects on native labor demand. Section 6 concludes the paper.

\section{Basic Aggregate Correlations}

We first consider simple correlations between the growth of the foreign-born population and the growth of wages and employment of natives. We aggregate US Census data for 1970 (2\% sample), 1980, 1990 and 2000 (5\% samples) and the 2008-2012 American Community Survey, which create a 5\% sample around 2010 that we use for that year. As main geographical unit of analysis we use 722 Commuting Zones (CZs) that encompass 
the 48 adjoining US states and are defined as to comprise the same residents and workers within themselves. They approximate local labor markets. We use the definition of Commuting Zone, and the concordance over time, as developed by Autor and Dorn (2013). Alternatively, we use 50 US states or 9 US Census regions as units of analysis. The samples that measure population in working age include all individuals between 18 and 64 years old not residing in group quarters, while those measuring employment only include individuals who worked a positive amount of weeks in the previous year. Finally, the samples constructed to measure wages include working individuals who received strictly positive wage income. We use the logarithm of weekly wages that we define as total income from wages divided by weeks worked in the previous year. ${ }^{2}$

Let us define as $F B_{i t}$ the number of foreign-born in working age in location $i$ and census year $t$. We then define as $U S B_{i t}$ the number of US born people in working age in the same location and census year. Our measure of the increase in immigrants (foreignborn) over an inter-census decade (for $t=1970,1980,1990,2000$ ) is the change in the number of foreign-born standardized by the initial population: $\Delta\left(i m m i_{i, t}\right)=\left(F B_{i, t+10}-\right.$ $\left.F B_{i t}\right) /\left(F B_{i t}+U S B_{i t}\right)$. This variable captures the increased number of immigrants relative to the local population in working age. Correspondingly, we define as $\Delta \ln \left(w_{a g e} e_{i, t}\right)^{U S B}$ the inter-census change in the logarithm of average weekly wages of native workers and as $\Delta\left(e m p l_{i, t}\right)^{U S B}$ the inter-census change in native employment as share of the population in working age in census year $t$. These variables capture the change in native workers' labor market outcomes over the considered decades measured as percentage points of the initial value. Figure 1 shows the variation of $\Delta\left(i m m i_{i, t}\right)$ across US CZs considering the whole 1970-2010 change and indicating with darker shades of grey the CZs with larger increase of immigrants. Several CZs in California, Texas and Florida, but also on the East Coast and in the Central States, show the largest values. Parts of the Midwest and some Mountain States show the smallest increases. Figure 2 shows the geography of the variable $\Delta \ln \left(\text { wage }_{i, t}\right)^{U S B}$ across CZs also considering the change for the whole 1970-2010 period. We observe some fast growing wages in CZs of Texas, Florida and on the East Coast, but also in the Mountain States.

As it is hard to discern positive or negative correlations from these maps we show in

\footnotetext{
${ }^{2}$ The detailed description of the samples, variables and their constructions using the IPUMS Census and ACS data (Ruggles et al. 2015) is in the Data Appendix. In general, we have used the same definitions of samples and variables as used in the book "Immigration Economics" By George Borjas (2014). All the dollar amounts are expressed in \$ as of 1999 adjusted using the BLS CPI-U All Items.
} 
Figure 3 the scatterplot of the decade changes $\Delta \ln \left(\text { wage }_{i, t}\right)^{U S B}$ on the vertical axis versus the change of immigrants, $\Delta\left(i m m i_{i, t}\right)$ on the horizontal axis, pooling decades (1970-2010) after we have subtracted common decade averages. The units of observation are CZs in a decade. We also report the regression line, its coefficient $(\beta)$ and the standard error (s.e.). The size of a circle in the graph is proportional to the population of the CZ. The plot clearly shows a strong and significant positive correlation between immigration and native wage increase. In fact, the coefficient is quite large and it implies that an increase of immigrants by 10 percentage points of the initial population in a $\mathrm{CZ}$, is associated to a native wage growth of $3.4 \%$. Figure 4 breaks down the correlation between immigrant inflow and native wages across four decades to see whether such association has changed systematically over time. The graph shows a non-significant coefficient for the 1970's and 1990's and a positive and significant coefficient for the 1980's and 2000's. While certainly the nature of labor market shocks across CZs has changed over these decades, introducing significant noise, we do not observe a systematic decrease (or increase) in the correlation between immigrants and native wages over time that could imply a systematic change in their role as competitors/complements of native workers. Overall, we observe positive or null correlations, with a fair amount of noise.

Looking at relatively small geographical units such as the CZs can provide an incomplete representation of the phenomenon. First, natives may offset the inflow of immigrants by leaving the area. Second, focussing on larger areas one can internalize some of the potential effects on wages that spilled over to other $\mathrm{CZs}$. To begin exploring these possibilities, therefore, in Figure 5 and 6 we show the correlation between native employment changes and immigration in scatterplots that mirror Figure 3 and 4. A strong role of immigrants in displacing natives would likely produce a negative correlation. A coefficient of -1 would be compatible with a strong displacement effect in which one immigrant replaces one native as worker. When pooling the observations across decades in Figure 5, as well as in the panels of Figure 6 where we show one chart per decade, we see either null or positive correlations between immigration and native employment. The pooled estimates show a positive correlation of 0.20 , not significantly different from 0. Across decades one finds a positive and significant coefficient in the 2000's and non significant coefficients in the other decades. Combining these correlation with those with native wages (zero to positive) it is clear that immigration is associated with a positive demand change for native workers across CZs. While the cause of such positive demand 
change for native workers cannot be inferred from these correlations directly, we can establish two minimal findings. First, locations where immigrants go are those where native labor markets are growing. This may certainly be driven by other factors, but at least the inflow of immigrants does not reverse the positive demand shock. Second, we have not found evidence of systematically changing correlation between native labor markets outcomes and immigrants over decades.

Before trying to control more systematically for some observed and unobserved determinants of native labor demand we consider an important differentiation in the labor market for native workers. Workers of different skills are subject to different degrees of immigrant competition and their schooling level is an important factor in determining such competition. Workers with different schooling levels can be considered as different and imperfectly substitutable labor inputs (see Borjas 2003, Ottaviano and Peri 2012 and Card 2009). In areas where immigrants are more skilled, highly educated natives could suffer more competition than less educated natives. To the contrary, a larger inflow of low educated immigrants produces competition for less educated natives and possibly complements the skills of highly educated. On average, the inflow of immigrants in the US during the considered period (1970-2010) has been largest among workers with no high school degree (low-skilled). Hence separating workers with low education (at most a high school degree) and those with high education (college educated or more), and still considering aggregate immigration in CZs as explanatory variables, we want to see if the correlation with native wages is consistent with a stronger competition effect on less educated natives. Figure 7 and 8 show the scatterplot of the increase of the log of weekly wages for natives with at most a high school diploma (Figure 7), or for natives with a college education (Figure 8) versus the increase in total foreign born as share of the total population. Two facts emerge. First, in both cases the correlation is positive and significant which confirms the idea that immigration is associated to a positive demand change for both types of native workers. Second, the correlation is stronger for college educated. While an increase in immigrants by one percentage point is associated to a 0.13 increase in non-college educated wages, college educated show a 0.42 percent grow. This is consistent with an overall positive demand (productivity) change associated with immigrants. If part of this association is causal it would be consistent with a stronger complementarity effect of immigrants on highly educated natives. 


\section{Correlations and Regression Analysis}

In order to analyze more systematically the correlations between immigrants and wage/employment of natives we perform several regressions. Those allow us to control for an array of omitted variables, some of them not observable (but common to location over time, or to decades across locations) and some observable, or at least proxied by variables that can be constructed, such as measures of technological change. We run two types of regressions in this section. The first set of regressions analyzes the impact of aggregate immigration in a location (as proxied by the immigrant share in the working age population of that area) either on native average performance (wage and employment) or on the performance of college educated or non-college educated separately. The estimated regressions are of the following type:

$$
\Delta\left(y_{i, t}\right)^{U S B}=\phi_{i}+\psi_{t}+\beta \Delta\left(i m m i_{i, t}\right)+\varepsilon_{i t}
$$

Where $\left(y_{i, t}\right)^{U S B}$ is an outcome (such as wage or employment) for all US born workers, or for an education group within them (college or non-college educated). The terms $\phi_{i}$ and $\psi_{t}$ are fixed location and time effects. The term $\varepsilon_{i t}$ captures a zero-mean random error. The coefficient of interest is $\beta$ and it describes the percent increase in the outcome variables associated to an increase of immigrants by one percentage point of the total population. These aggregate regressions aim at capturing the overall association between immigrants as a whole and native outcomes. The limit of these regressions is that, if other factors are not controlled for, the correlation is not informative of the causal effect of immigrants on native outcomes.

A second group of regressions analyzes instead the correlation between immigrants and native outcomes within skill-location cells. The skill cells are defined as four education groups (no degree, high school degree, some college and college degree) by two experience groups (at most twenty years of experience and more than twenty years of experience). By selecting natives and immigrants in the same cell one is considering similar type of workers, more likely to compete for similar jobs. By including fixed terms that control for location-decade effects one is likely to absorb some of the omitted variables that may bias the previous regression (1) hence reducing the risk of spurious correlations. However such a strategy also absorbs with the fixed effects all the possible cross-skill complementarity and aggregate externalities that immigrants workers generate. Namely, in these regressions 
we estimate the effect of immigrants in the same skill group and location, considering those in other skill-group in the same location as constant. While these regressions are informative and allow us to include a much larger number of fixed effects as controls, one has to emphasize the partial nature of the estimates that they produce. The estimated regressions are of the form:

$$
\Delta\left(y_{i, k, t}\right)^{U S B}=\phi_{i}+\phi_{t}+\phi_{k}+\phi_{i, k}+\phi_{i, t}+\phi_{k, t}+\beta \Delta\left(i m m i_{i, t}\right)+\varepsilon_{i t}
$$

Where the index $k$ denotes the skill groups (eight of them divided into four education by two experience groups) and the fixed effects include area, decade and skill effects plus fixed effects for all the interactions between two of those attributes ${ }^{3}$. The value of $\beta$ in these type of regressions has been considered as an estimate of the effect of immigrants on natives in some studies (e.g. in Borjas 2014). However, even abstracting from omitted variable bias this is at best, as pointed out in Ottaviano and Peri (2012), a partial, ownskill effect of immigrants, reflecting only the impact on most similar natives' wages and absorbing the cross-skill complementarity and externalities in the area in the time-area effects. If we were to omit the set of $\phi_{i, t}$ effects in the estimates then the regressions might provide an average estimate of the own plus cross effects of immigrants, as long as other omitted variables do not bias those effects.

\subsection{Area Regressions: Average Effects}

Table 1 shows the estimated coefficient $\beta$ from the aggregate regressions as in (1) when the dependent variable is the change in logarithm of average weekly wage for natives. The difference between columns is given by the geographical units of observation considered. In column (1) the regression is run using observations for 722 Commuting Zones over four decades. In column (2) we use 50 States over four decades and in column (3) we use 9 Census regions over four decades. Across rows we estimate somewhat different specifications. Row (1) includes only decade fixed effects while row (2) has decade and geographic unit fixed effects. Row (2) is our preferred specification. In the row (3) we omit the earlier decade (1970-80), while in row (4) we include the most recent decade of data (2000-2010) only. Large changes in estimates across samples could reveal a systematically changing nature of the link between immigration and wages consistent, for instance, of

\footnotetext{
${ }^{3}$ As usual, when including the cross-group effects one needs to omit the individual group effects, as they are fully absorbed in the interactions.
} 
significant spillovers out of the smaller geographical units. In the two bottom rows we omit the smallest $10 \%$ of $\mathrm{CZs}$ and the largest $10 \%$ to see if extreme values drive the correlation. Most of the estimated coefficients using CZs are not far from 0.4, and when using larger geographical units the coefficient is also, usually around 0.4, but has some variance as it can be as low as 0.27 and as large as $0.60 .^{4}$ In most cases we cannot reject the hypothesis that, for specifications in one row, the coefficients are the same across all geographical units (columns 1 to 3 ). This suggests that spillovers of a potential causal impact of immigrants are not so relevant as to invalidate correlations taken at the level of a labor market. The relationship between immigrants and wages is stable across specifications, geographical units and decades. While imprecision of the estimates limits our confidence in any individual specification, taken together these estimates seems to show a significantly positive correlation coefficient around 0.4 .

Table 2 then shows the aggregate correlation between immigrants and native employment. In this case most of the estimates are not significantly different from 0 . When focussing on the last decade (row 4) and on smaller CZs (row 6) one gets imprecisely estimated positive correlations. Considering our preferred estimates in row (2) we observe stable and consistently small and non-significant estimates of the correlation between immigration and native employment across all geographical units. No systematic difference in the correlation between immigrants and native employment emerged across CZs, States or Census regions when considering specifications in row (2). In particular, none of the correlations is suggestive of displacement of natives that would imply a negative and significant coefficient. Combining all wage and employment correlations, the area regressions confirm the impression produced by the simple scatterplots. Immigration is associated, on average, with an increase in demand for native workers and such association exists at the very local (CZs) as well as the broader (Census region) geographical level. If immigrants are purely attracted by aggregate local demand shocks then these effects are consistent with immigrants responding to those as natives do. ${ }^{5}$ But can we control for some of those shocks? And can we analyze if the association between immigration and native labor demand in specific skill groups is very different from this average effect? In

\footnotetext{
${ }^{4}$ The highest value for the region regression is 1.35 in the last row of column (3). As there are only 9 regions the regression is rather imprecise and standard error is quite large.

${ }^{5}$ Recent analysis by Cadena and Kovak (2015) finds that low skilled immigrants respond to local demand shocks more than natives. Their analysis is based on short-run variations but the high mobility of immigrants can certainly be part of the reason for the positive correlation between native share of the population and native wages and employment growth.
} 
the next section we will analyze the skill structure of labor markets and the competition effect of immigrants on similar workers.

\subsection{Area-Skill-Cell Regressions: Partial Effects}

Table 3 reports the estimates of coefficient $\beta$ for different specifications of regression (2). In particular, those differ across columns for the geographical units used as observations (in column (1) the units are Commuting Zones-by-skill in column (2) they are Statesby-skill in column (3) they are Census regions-by-skill). They differ across rows for the progressive inclusion of more fixed effects (only area, skill and decade effects in row (1), area-skill interactions and decade effects in row (2), area-skill and skill-decade interactions in row (3) and all the two-way interactions in row (4)). The last row excludes the 1970-80 decade from the analysis.

The coefficients in row (4) estimate the own-skill partial effect of immigrants in the skill-group and area once we control for total immigration in the area (that is captured by the area-time fixed effects). Those values are close to 0 . This is consistent with a framework in which native and immigrants in a skill group are different enough that the competition effect of similar immigrants is balanced by their complementarity effect resulting in no wage impact. The other specifications, not including area-decade effects, identify the average effect of combining own and cross-skill. Those are positive or close to zero. In particular, the effects are attenuated and more imprecisely estimated at the Census region level. This may be due to smaller variation as we are averaging across areas with very different inflows of immigrants.

Table 4 shows the same specifications with the change in native employment as dependent variable. Even in this case we observe positive and significant coefficients in the first two rows, and non-significant coefficients in the other rows. These estimates are consistent with a world in which either complementarity between immigrants and natives prevails, or positive demand shocks for natives accompany inflow of immigrants in the same area and skill group. They are not compatible, however, with a situation in which supply driven changes in immigrants displace natives or depress their wages.

\subsection{Area Regressions for More or Less Educated Natives}

The combination of results from Tables 1 and 2 is consistent with a scenario in which the inflow of immigrants is associated with a positive increase in demand for native work- 
ers due to complementarity or externalities, together with a small competition effect on native workers of similar skills. The cell-level analysis is useful to capture the fact that, controlling for overall immigration in an area, skill groups with larger increase of immigrants do not experience especially negative or positive outcomes. Hence a part of the positive aggregate effect in Table 1 must come from cross-group complementarity or externalities. To learn how the complementarity-externality and competition effects (plus potential omitted variables) influence wages and employment of natives in different skill groups, we focus on more and less educated in separate regressions. In Table 5 we show the effect on average log weekly wages of high school educated natives (upper part of the table) and of college educated natives (lower part) separately. We estimate specification (1) with the outcome $\Delta \ln \left(\text { wage }_{i, t}\right)^{U S B}$ measured separately for each of the two education groups. If immigration, as it appears so far, is accompanied by constant or increased labor demand for native workers, with a larger boost for college educated natives, we should observe zero or positive estimates in all entries and larger point estimates in the bottom part of the table. This is exactly what we find. In specification (2), across columns, we find correlation consistent with the fact that a $0.2-0.3 \%$ increase in less educated wages is associated to one percentage point increase of immigrants in the population, and a 0.4-0.6\% increase for college educated native wages is associated to the same increase of immigrants. Limiting ourselves to the last decade, precision is lacking, but we find more balanced effects on the two groups, consistently with the more college-intensive immigration of the recent decade. While only suggestive, these correlations overall are consistent with immigration being beneficial to native labor demand, especially for college educated.

\section{Omitted Variables and Identification of Causality}

One important reason for the different performance of labor markets across locations during the last decades has been the very different economic success of different industries. High tech sectors in manufacturing and services have increased much their productivity, propelled by the information and communication technology revolution and their demand for workers especially of highly educated ones has surged. To the contrary part of the manufacturing and service sector, characterized by simple, routine and non-cognitive type of occupations have experienced stagnant wages and employment (e.g. Acemoglu and Autor, 2011; Autor and Dorn 2013). As different geographical areas have different specialization, some have suffered more from the decline of low performing industries and 
other have benefitted more from the expansion of fast growing ones. Here we use the different industry specialization of Commuting Zones in year 1970, and the differential growth of wages across those industries, to construct an index of local sector-driven labor demand. We then include this control that captures sector-driven labor demand growth and we test whether the positive correlation between immigrants and native wage growth survives.

Specifically, we construct an index of sector-specific growth, often called "Bartik" instrument (from Bartik, 1991), as follows. Let us define as $s h_{i j, 1970}^{E M P L}$ the share of employment in industry $j$ in the total employment of $\mathrm{CZ} i$, and let $\Delta \ln w a g e_{j t}$ be the growth of the log weekly average wages for workers in industry $j$ nationally between year 1970 and year $t$. Then the proxy for industry-driven growth in labor productivity (labor demand) for workers in $\mathrm{CZ} i$ will be defined as:

$$
\Delta \text { Bartik }_{i t}=\sum_{j}\left(\operatorname{sh}_{i j, 1970}^{E M P L} \Delta \ln \text { wage }_{j t}\right) \quad \text { for } t=1980,1990,2000,2010
$$

This index will be included as control in the regressions of Table 5. Table 6 shows the results of specifications (1) and (2) of Table 5, estimated for CZs only and controlling for $\Delta$ Bartik $_{i t}$, the proxy for labor demand growth. Considering the more demanding specification (2) we see that, while the demand growth proxied by $\Delta B_{a r t i} k_{i t}$ is itself a very important determinant of native wage growth for college and non-college educated, its inclusion does not eliminate the positive and significant correlation between native wages and growth in immigrant population. We still estimate a $0.2 \%$ increase in the wage of non-college educated natives per percentage point of foreigners and a $0.4 \%$ increase for wages of college educated natives.

An alternative way of making progress towards identification of the causal effect of immigrants on native labor market outcomes is, rather than controlling for demand changes, to construct a proxy for the supply-driven shifts of the immigrant population. We then use that as an instrumental variable for the changes in immigrants as share of the population. A popular way of doing this is to construct a so-called "shift-share" instrument (as suggested by Altonji and Card 1991, Card 2001 and used in several papers since then) using $F B_{i, c, t_{0}}$, the population of immigrants by nationality $(c)$, across US CZs $(i)$ in year $t_{0}$, that should be prior to the considered period, and augment these populations by the aggregate growth factor of immigrants from that nationality $c$ in the US between year $t_{0}$ and $t, \frac{F B_{c, t}}{F B_{c, t 0}}$. This instrument is based on the idea that the distribution of foreign born of 
nationality $c$ in $\mathrm{CZ} i$ in $t_{0}$ is uncorrelated with subsequent demand shifts and productivity changes in that $\mathrm{CZ}$. In our case we would instrument the variable $\Delta\left(i m m i_{i, t}\right)$ with the following imputed value:

$$
\Delta\left(\widehat{i m m} i_{i, t}\right)=\frac{\widehat{F B_{i t}}-F \widehat{B_{i t}-10}}{F \widehat{B i t-10}_{i S B_{i t-10}}} \text { where } \widehat{F B_{i t}}=\sum_{c} F B_{i, c, t_{0}} * \frac{F B_{c, t}}{F B_{c, t_{0}}}
$$

We will use in the analysis only the decade changes from 1980 to 2010, and as "initial year" $t_{0}$ we choose alternatively 1980 or 1970 . The choice of an earlier year reduces the chance that persistent labor demand shocks drive both the distribution of foreigners by nationality in $t_{0}$ and the native worker productivity growth in the subsequent decades. Hence one may think that $t_{0}=1970$ is the better choice. The instruments so constructed are reasonably strong (F-statistics of 92.5 for the one with base-year 1970 and 51.5 for the one based on 1980, as shown in Table 7). One cannot still be sure that the distribution of immigrants in 1980 or even 1970 is fully exogenous to post-1980 demand shocks and hence we still need to be careful in interpreting the results. Past immigrants may have located following past demand shocks and a long-run persistence of these shocks could threaten the exclusion restriction and introduce omitted variable bias. Table 7 shows the 2SLS estimates of the same specification as row (1) of Table 5, for CZs only, including decade fixed effects and using the shift-share instrument. The first row shows estimates using IV based in 1970, while the second row shows the same estimates with IV based in 1980. We only include the three decade changes from 1980 and 2010 in the analysis. Two things emerge. While the point estimates of the average effect and of the effect on college educated is very similar to the OLS estimates, the standard error for each coefficient increases significantly so that two out of four estimates are not any longer significant, although still positive and large. Second, the point estimates on the wage of less educated native workers is reduced (now the point estimate is negative) and the standard error is larger so that we do not estimate any significant effect on the wage of that group. By better isolating supply shocks linked to the country of origin of immigrants we may have gotten closer to a genuine causal estimate (with the caveat mentioned above). What we observe is a non-significant effect on less educated, a positive effect on college educated, and an overall positive but non-significant average effect.

The small and non-significant association of immigrants with wages of less educated native workers and the positive association with wages of college educated that emerges from the last 2SLS estimates, are consistent with the results obtained using a variety 
of methods and approaches. In the existing literature, both model based-approaches (Peri and Sparber 2009, Ottaviano and Peri 2012, Ottaviano et al. 2013, D'Amuri and Peri 2015, Peri 2012) and reduced form approaches (Ottaviano and Peri 2006, Ortega and Peri 2015) show a positive average association of immigration with native wages, and a smaller correlation with wages of less educated and a larger one with wages of more educated natives. Overall, we think that the series of simple correlation presented in this paper, while certainly not exhaustive, are urging us to understand better how local economies in the US, and the national economy as a whole, absorb immigrants and generate adjustment and new options for natives along several margins, which could produce positive employment and wage effects.

Recent research trying to identify the effect of immigration on native wages has focussed on the possibility of using new identification strategies, namely changes in the supply of immigrants not simply linked to the shift-share proxy. Often these papers rely on changes in national policies that had differential regional effects, or combination of policies and specific push-episodes from countries of origin that produce a sudden supply shock. The problem is, often, that interesting policy changes and large push-driven migrations are not available for all countries and hence this identification strategy is only applicable to some specific cases. Some studies have tried to classify systematically immigration policies across countries and they identify episodes of policy changes to see if and how much they affected immigration (Ortega and Peri 2013, Docquier, Peri and Ruyssen 2014) with the intention of creating an international database of policies. Using such data would allow us to use response to policy changes as supply shocks. Some recent papers have used specific policies to that purpose. For instance, Foged and Peri (forthcoming) uses the surge in Bosnian refugees to Denmark during the Bosnian war (1993-1995) and the Danish refugee dispersal policy as exogenous supply shocks across Danish municipalities. The paper can then track the effects of differential refugees inflow on native labor market outcomes and it finds a positive wage impact around $1 \%$ for an increase of refugees by one percent of the population. This is due to refugees taking manual jobs and pushing natives to take more complex jobs, with career upgrade and pay increases. Beerli and Peri (2015) uses instead the opening of the Swiss border to mobility of workers from the European Union between 1999 and 2004. Such process had different timing in two types of Swiss regions and the authors use such different timing to perform a difference in difference analysis of immigrant inflows and labor market outcomes. They find very 
small and not significant average effects on native wages and employment.

Considering all evidence together it appears that to understand the connection between immigration and native wages and employment one needs to envision mechanisms in which local economies respond to immigration with a possible increase in the demand for native workers. We will describe very briefly some of them in the next section.

\section{Possible Adjustment Mechanisms}

The key factors to understand the potentially positive effects of immigrants on demand for native workers are three. First, immigrant and natives are different types of workers, and they complement each other up to a certain degree. Second, immigrants may induce changes in efficiency, specialization and technology adopted by native firms with positive impact on all workers. Third, immigrants, especially the highly educated, may have positive external effects due to their impact on innovation and new ideas. Let us briefly review these arguments.

First, as pointed out in Ottaviano and Peri (2006) and Ottaviano and Peri (2012), immigrants, even with similar schooling and education as natives, tend to do different jobs from them. They bring different culture, different language skills, different abilities and these factors differentiate them from natives. A natural dimension to think of this differentiation is that immigrants have a comparative advantage in manual tasks relative to language ones (Peri and Sparber 2009). Hence they will not so much compete directly with natives, as they will create conditions for increased specialization where natives do more communication-intensive jobs and immigrants do manual-type of tasks. This can imply gains in productivity (Peri 2012, Ottaviano et al 2013). However, the differentiation may also be along other dimensions. The services that immigrants provide, the products that they manufacture are different from natives'. The complementarity/diversity of tasks may drive efficient specialization and this implies gains in efficiency. But also the increased diversity in productive services itself may be beneficial to production. The added benefits from efficiency and diversity are the second reason that will result in higher wages and more demand for the skills of native workers.

But it is not all. Some immigrants may have an especially positive effects on native productivity and growth of the economy (Hunt and Gauthier-Loiselle 2010). Highly skilled immigrants are largely scientists and engineers in the US (Peri, Shih and Sparber 2015) and their contribution to ideas, innovation and new technologies drives higher productivity 
and higher income for everybody in the US economy (Kerr and Lincoln 2010). A positive externality from high human capital (as in Moretti 2004, or Docquier, Ozden and Peri 2014), or specifically from their role as scientists and engineers (as in Peri, Shih and Sparber 2015), or simply from their diversity in abilities and ideas (as in Ortega and Peri 2014), are likely to be an added boost to US growth. In fact, in a dynamic perspective the growth from more varied and better ideas can be the most important positive contribution of immigrants to the US economy. ${ }^{6}$

\section{Conclusions}

In this review paper we have presented a battery of simple, yet increasingly demanding correlations between immigrant population and native wages and employment across areas of the United States. The prevailing fact emerging is an association of immigrants with zero to positive changes in the demand for native workers. This is true at any geographical level, for individual skill-level and in the aggregate and both when using employment and wages. We have tried to rule out spurious determinants of this correlation by including measures of local technology or common geographical factors, and the correlation has remained, possibly attenuated for less educated native workers. Certainly we have not been able to exhaust all omitted variables. Yet, these descriptive correlations result from partial correlation coefficients with a rich set of controls and help us understand how immigrant-induced supply shocks affect wages and employment of natives at the local level. Moreover, we carefully defined our independent variable of interest as the flow of migrants of a given skill group to an area between two census years, normalized by the beginning of decade supply of labor in the same skill group. In contrast to this approach, one could use the change in the stock of migrants in an area for a given skill group and decade (see Borjas 2015). However, as recently noted by Card and Peri (forthcoming), this latter approach would introduce a negative bias in the correlation between migration and native wages, and a source of spurious correlation between migration and the change in the number of natives in a given skill group.

Nevertheless, the prevalence of positive correlations implies that we should explore seriously models and frameworks in which the local absorption of immigrants may gener-

\footnotetext{
${ }^{6}$ Borjas and Doran $(2012,2015)$ analyze the case study of academic mathematicians inflows to the US after the collapse of the Soviet Union. While they find displacement of US academics to lower quality academic jobs and nonAzacademic positions, it is less clear how this event is generalizable to the effects of high-skill migration on the economy due to the relatively rigid structure of the academic market.
} 
ates an increase (or no change) in the demand for native workers. The literature briefly reviewed in the previous section does this by collecting model-based empirical analysis that provides a structural interpretation to the estimated parameters, and uses them to assess the substitutability of immigrants and natives and the impact of immigrants (and emigrants) on the productivity of natives. The literature often adopts a "production function" framework based on a nested CES approach, and search specifically for productivity enhancing effects through spillovers, specialization, innovation. While the estimates resulting from this approach may be sensitive to assumptions (as noted by Borjas 2014), all the empirical evidence points to small effects of immigration on natives' labor market outcomes (Card and Peri forthcoming). More recently, researchers recognize that immigration policies are the leverage that country have to affect immigration and its changes, and they have tried to measure these policies and to leverage them in the analysis of the impact of immigrants on economic outcomes. This quasi-experimental approach has also revealed only small effects of migration on natives' labor market outcomes consistent with those estimated by the previous literature. 


\section{References}

[1] Acemoglu, Daron and David Autor. (2011). "Skills, Tasks and Technologies: Implications for Employment and Earnings." Handbook of Labor Economics, vol. 4B, pages 1043-1171.

[2] Altonji, Joseph G. and David Card (1991). "The Effects of Immigration on the Labor Market Outcomes of Less-skilled Natives," NBER Chapters, in: Immigration, Trade, and the Labor Market, pages 201-234 National Bureau of Economic Research, Inc.

[3] Autor, David and David Dorn (2013). The Growth of Low-Skill Service Jobs and the Polarization of the US Labor Market American Economic Review 2013, vol. 103(5), pages $1553-1597$.

[4] Autor, David, David Dorn and Gordon H. Hanson, (2013). "The China Syndrome: Local Labor Market Effects of Import Competition in the United States," American Economic Review, American Economic Association, vol. 103(6), pages 2121-2168, October.

[5] Bartik, Timothy J. (1991). "The Effects of Metropolitan Job Growth on the Size Distribution of Family Income," Upjohn Working Papers and Journal Articles 91-06, W.E. Upjohn Institute for Employment Research.

[6] Beerli, Andreas and Giovanni Peri (2015). "The Labor Market Effects of Opening the Border: New Evidence from Switzerland," NBER Working Papers 21319, National Bureau of Economic Research, Inc.

[7] Borjas, George J. (2003). "The Labor Demand Curve Is Downward Sloping: Reexamining The Impact Of Immigration On The Labor Market," Quarterly Journal of Economics, MIT Press, vol. 118(4), pages 1335-1374, November.

[8] Borjas, George J. (2014). "Immigration Economics" Harvard University Press.

[9] Borjas, George J., Richard B. Freeman and Lawrence F. Katz (1997). "How Much Do Immigration and Trade Affect Labor Market Outcomes?," Brookings Papers on Economic Activity, Economic Studies Program, The Brookings Institution, vol. 28(1), pages $1-90$. 
[10] Borjas, George J. and Kirk B. Doran (2012). "The Collapse of the Soviet Union and the Productivity of American Mathematicians." Quarterly Journal of Economics, vol. 127(3), pages 1143-1203.

[11] Borjas, George J. and Kirk B. Doran (2015). "Cognitive Mobility: Labor Market Responses to Supply Shocks in the Space of Ideas," Journal of Labor Economics, University of Chicago Press, vol. 33(S1), pages S109-S145.

[12] Card, David (1990). "The impact of the Mariel boatlift on the Miami labor market," Industrial and Labor Relations Review, ILR Review, Cornell University, ILR School, vol. 43(2), pages 245-257, January.

[13] Card, David (2001). "Immigrant Inflows, Native Outflows, and the Local Labor Market Impacts of Higher Immigration," Journal of Labor Economics, University of Chicago Press, vol. 19(1), pages 22-64, January.

[14] Card, David (2009). "Immigration and Inequality," American Economic Review, American Economic Association, vol. 99(2), pages 1-21, May.

[15] Card, David and Giovanni Peri (forthcoming). "Immigration Economics: A Review," fortcoming in the Journal of Economic Literature, American Economic Association.

[16] D'Amuri, Francesco, Gianmarco I.P. Ottaviano and Giovanni Peri (2010). "The labor market impact of immigration in Western Germany in the 1990s," European Economic Review, Elsevier, vol. 54(4), pages 550-570, May.

[17] D'Amuri, Francesco and Giovanni Peri (2014). "Immigration, Jobs, And Employment Protection: Evidence From Europe Before And During The Great Recession," Journal of the European Economic Association, European Economic Association, vol. 12(2), pages 432-464, April.

[18] Docquier, Frédéric, Çağlar Ozden and Giovanni Peri (2014). "The Labour Market Effects of Immigration and Emigration in OECD Countries," Economic Journal, Royal Economic Society, vol. 124(579), pages 1106-1145, September.

[19] Docquier, Frédéric, Giovanni Peri and Ilse Ruyssen (2014). "The Cross-country Determinants of Potential and Actual Migration," International Migration Review, Wiley Blackwell, vol. 48, pages S37-S99, September. 
[20] Friedberg, Rachel M. (2001). "The Impact Of Mass Migration On The Israeli Labor Market," Quarterly Journal of Economics, MIT Press, vol. 116(4), pages 1373-1408, November.

[21] Friedberg, Rachel M. and Jennifer Hunt (1995). "The Impact of Immigrants on Host Country Wages, Employment and Growth," Journal of Economic Perspectives, American Economic Association, vol. 9(2), pages 23-44, Spring.

[22] Foged, Mette and Giovanni Peri (forthcoming). "Immigrants' Effect on Native Workers: New Analysis on Longitudinal Data," forthcoming in the American Economic Journal: Applied Economics.

[23] Grossman, Jean Baldwin (1982). "The Substitutability of Natives and Immigrants in Production," The Review of Economics and Statistics, MIT Press, vol. 64(4), pages 596-603, November.

[24] Hunt, Jennifer and Marjolaine Gauthier-Loiselle (2010). "How Much Does Immigration Boost Innovation?" American Economic Journal: Macroeconomics, American Economic Association, vol. 2(2), pages 31-56.

[25] Kerr, William and William F. Lincoln (2010). "The Supply Side of Innovation: H-1B Visa Reforms and U.S. Ethnic Invention." Journal of Labor Economics, vol. 28(3), pages 473-508.

[26] Ottaviano, Gianmarco I. P. and Giovanni Peri (2012). "Rethinking The Effect Of Immigration On Wages," Journal of the European Economic Association, European Economic Association, vol. 10(1), pages 152-197, February.

[27] Ottaviano, Gianmarco I. P., Giovanni Peri and Greg C. Wright (2013). "Immigration, Offshoring, and American Jobs," American Economic Review, American Economic Association, vol. 103(5), pages 1925-59, August.

[28] Ortega, Francesc and Giovanni Peri (2014). "Openness and income: The roles of trade and migration," Journal of International Economics, Elsevier, vol. 92(2), pages 231-251.

[29] Peri, Giovanni (2012). "The Effect Of Immigration On Productivity: Evidence From U.S. States," The Review of Economics and Statistics, MIT Press, vol. 94(1), pages 348-358, February. 
[30] Peri, Giovanni and Chad Sparber (2009). "Task Specialization, Immigration, and Wages," American Economic Journal: Applied Economics, American Economic Association, vol. 1(3), pages 135-69, July.

[31] Peri, Giovanni, Kevin Shih and Chad Sparber (2015). "STEM Workers, H-1B Visas, and Productivity in US Cities," Journal of Labor Economics, University of Chicago Press, vol. 33(S1), pages S225 - S255.

[32] Ruggles, Steven, Katie Genadek, Ronald Goeken, Josiah Grover, and Matthew Sobek (2015). "Integrated Public Use Microdata Series: Version 6.0 [Machine-readable database]." Minneapolis: University of Minnesota. 


\section{Appendix: Data}

The data used to construct our dependent and independent variables are drawn from the US Census public use microdata as available from IPUMS (Ruggles et al. 2015). We use data from 1970 (aggregating two 1\% metropolitan area samples), 1980, 1990 and 2000 (5\% samples), as well as the 2008-2012 American Community Survey, which creates a $5 \%$ sample around 2010 that we use for that year. The samples that measure population include all individuals age 18-64 not residing in group quarters, while the employment sample only include individuals who worked a positive amount of weeks in the previous year. The population and employment samples are weighted by the Census personal weight. The samples used to measure wages include individuals age 18-64, who are not attending school at the time of the survey, who worked a positive amount of hours and weeks in the previous year, and who received strictly positive wage income. We also exclude from the wage sample self-employed and unpaid family workers. The measure of wage used throughout the paper is the logarithm of weekly wages that we define as the total income from wages divided by weeks worked in the previous year. Top-coded income from wages observations are multiplied by 1.5. All the dollar amounts are expressed in $\$$ as of 1999 adjusted using the BLS CPI-U All Items. The wage samples are weighted by the product of the Census personal weight and the number of weeks worked in the previous year.

All the dependent variables used in the paper are for the native population only. We define as foreign born, or immigrants, all the individuals who are born abroad, including those who become naturalized citizens. We define low-skilled workers (or "high school or less") as those with either 12 completed years of schooling and/or a high school or equivalent diploma, and as high-skilled workers (or "college or more") those with at least one year of college or more. We also breakdown these definitions further into four groups:

high school dropouts (with less than 12 years of schooling), high school graduates (12 years of schooling and/or a high school or equivalent diploma), some college (at least one year of college and/or an Associate's degree), college graduates or more (Bachelor's degree or higher). Finally, we define two experience groups: workers with at most twenty years of experience, and more than twenty years of experience.

We use as main geographical unit of analysis 722 Commuting Zones that encompass the 48 adjoining US states, thus dropping Alaska and Hawaii. Commuting Zones are clusters of counties that are characterized by strong within-cluster and weak between- 
cluster commuting ties, thus capturing the boundaries of local labor markets. In order to match the geographic information contained in the IPUMS data (County Group in the 1970 and 1980 Census, PUMA in the 1990 and 2000 Census, and in the 2008-2012 ACS) to Commuting Zones we use the crosswalk developed by Autor and Dorn (2013) (as available on David Dorn's website, http://www.ddorn.net/data.htm). Hence we multiply the person weights and labor supply weights described above with an adjustment factor that accounts for the fraction of a County Group/PUMA that maps to a given Commuting Zone. Alternatively, we use 50 US states or 9 US Census regions as geographic units as available in IPUMS.

The description of the "Bartik" instrument, from Bartik (1991), is given in the text. The sector definition is based on 45 industrial sectors that are consistently identifiable in the 1970-2010 IPUMS samples. The wage growth measure is based on the sectoral log weekly average wages, which we defined above. The "enclave" instrument, described in the text, is based on the immigrants' country of birth that we aggregate into 15 country groups consistent across samples.

All the programs used in this paper are available for download from http://gaetanobasso.ucdavis.edu/data-code.html. 
Figure 1

Change in Foreign-born as share of initial population

Commuting Zones,Changes1970-2010

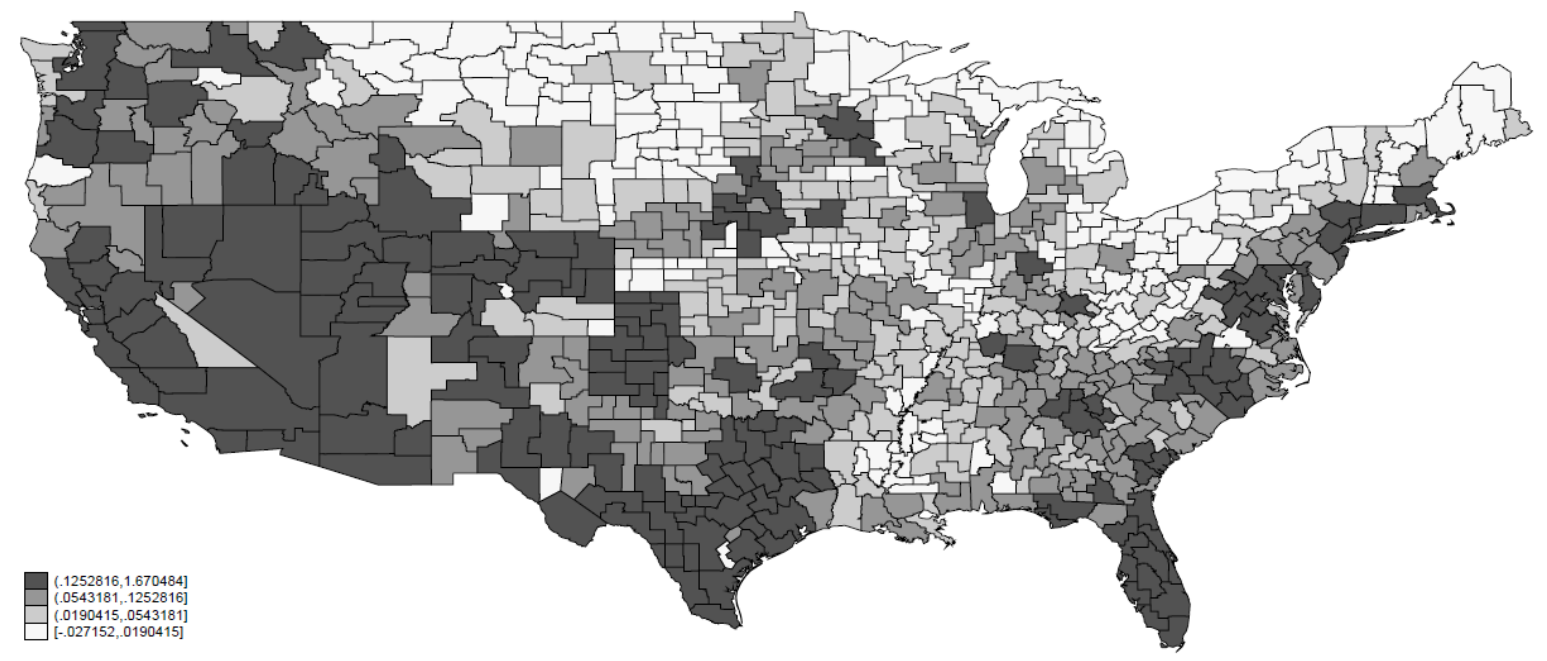

Note: Our calculations based on Census and ACS data from Census 1970, 80, 90, 2000 and 2010. The definition of the variable represented is given in the text. Units are 722 Commuting Zones.

Figure 2

Change in the logarithm of weekly wages of natives

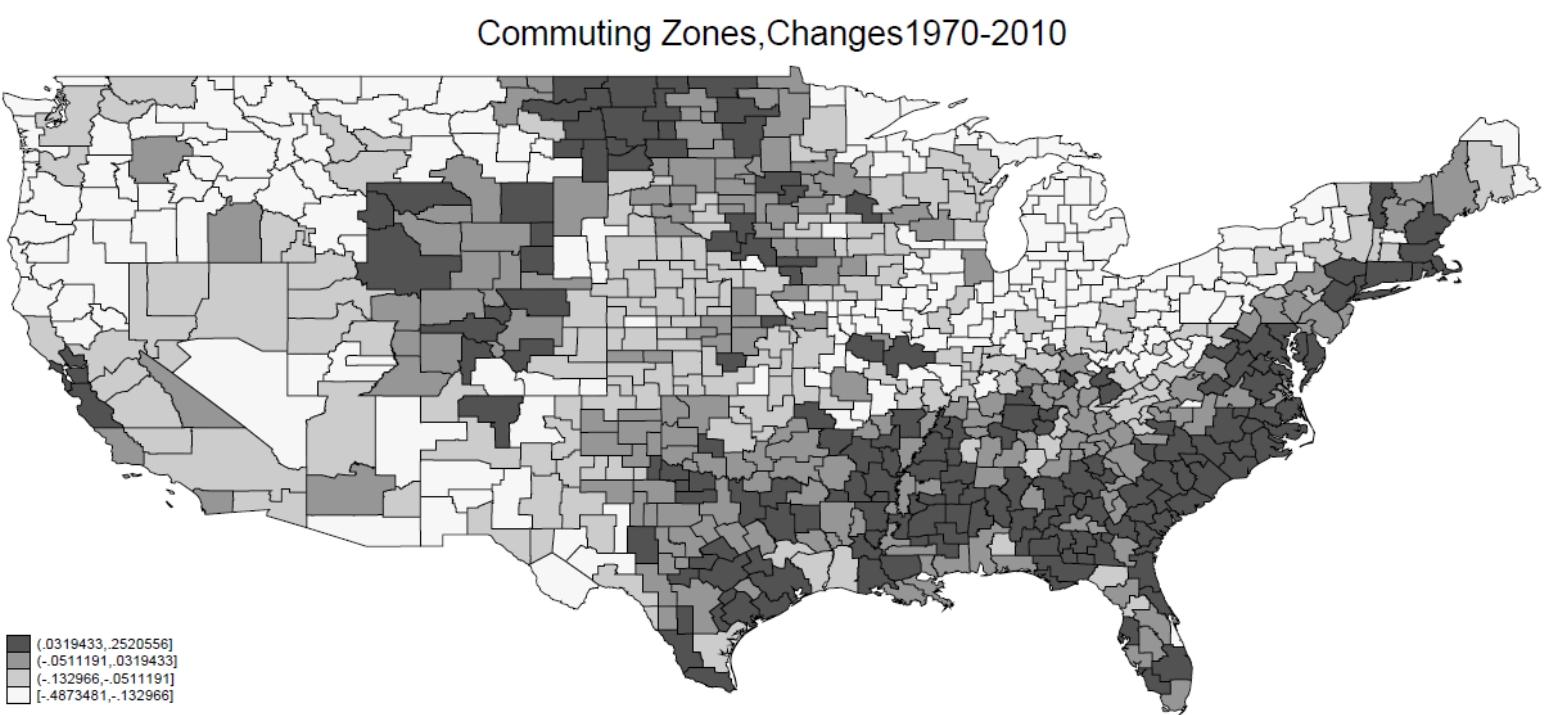

Note: Our calculations based on Census and ACS data from Census 1970, 80, 90, 2000 and 2010. The definition of the variable represented is given in the text. Units are 722 Commuting Zones. 
Figure 3

Change in immigrants and change in weekly wages of natives

Commuting Zones per decade, pooled 1970-2010

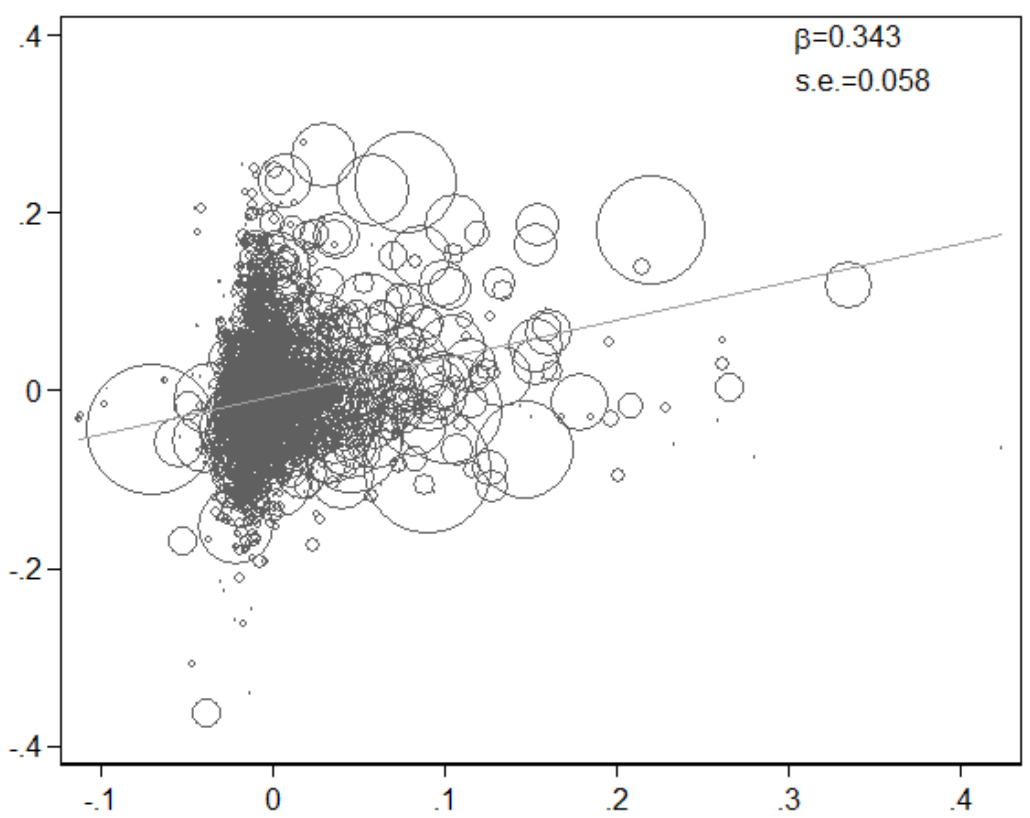

Note: The vertical axis shows the change in logarithmic weekly wages for natives, the horizontal axis shows the change in foreign-born as share of initial population. Unit of observation is a CZ in a decade. The changes are cleaned from the decade average. The size of the circle is proportional to the beginning of decade population in the $\mathrm{CZ}$.

Figure 4

Change in immigrants and change in weekly wages of natives

Commuting Zones separately by decade
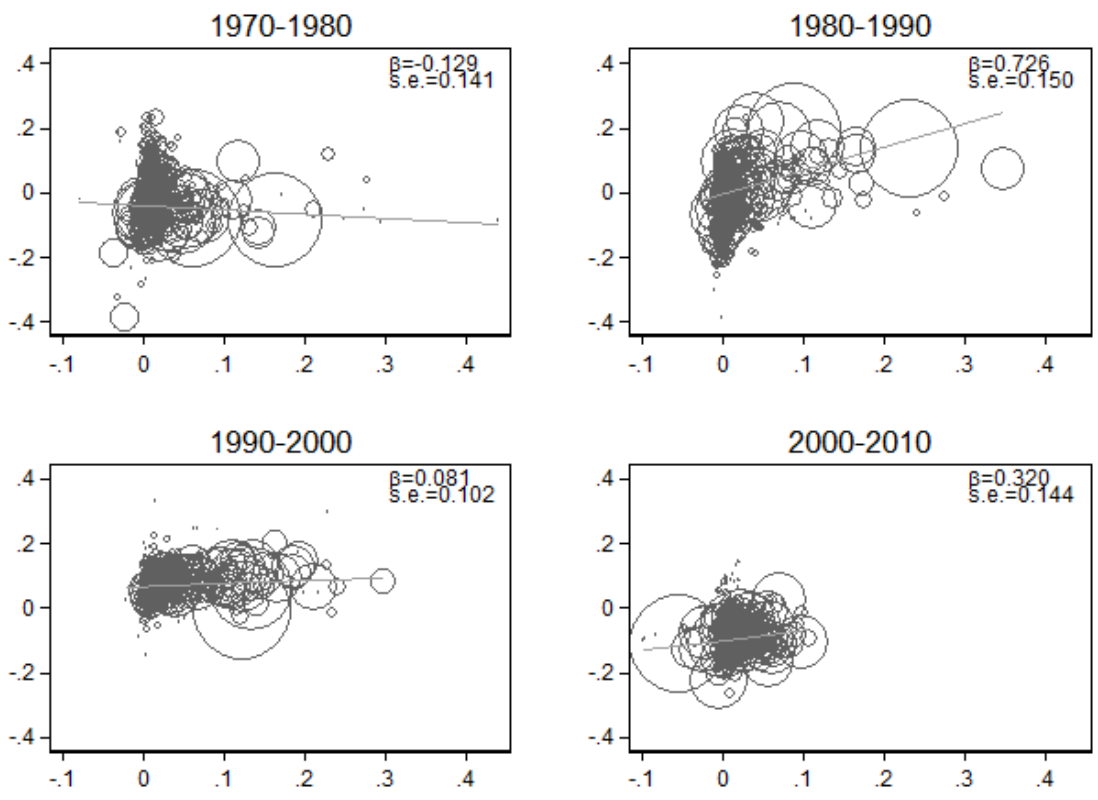

Note: Each panel shows the decade-change in logarithmic weekly wages for natives (vertical axis), and the decade-change in foreign-born as share of initial population (horizontal axis). Unit of observation is a CZ in a decade. The size of the circle is proportional to the beginning of decade population in the CZ. 
Figure 5

Change in immigrants and change native employment Commuting Zones per decade, pooled 1970-2010

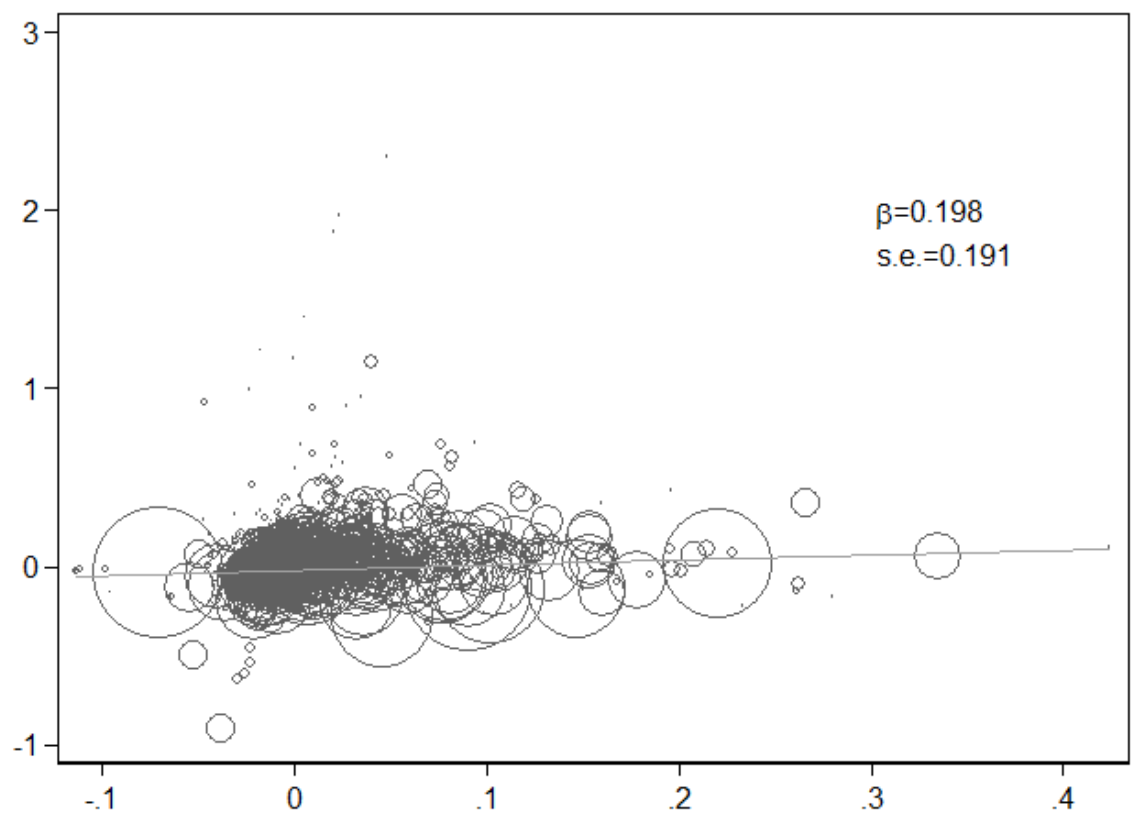

Note: The vertical axis shows the change in native employment relative to total employment at the beginning of the decade. The horizontal axis shows the change in foreign-born as share of initial population. Unit of observation is a CZ in a decade. The changes are cleaned from the decade average. The size of the circle is proportional to the beginning of decade population in the CZ.

\section{Figure 6}

\section{Change in immigrants and change in native employment}

Commuting Zones separately by decade
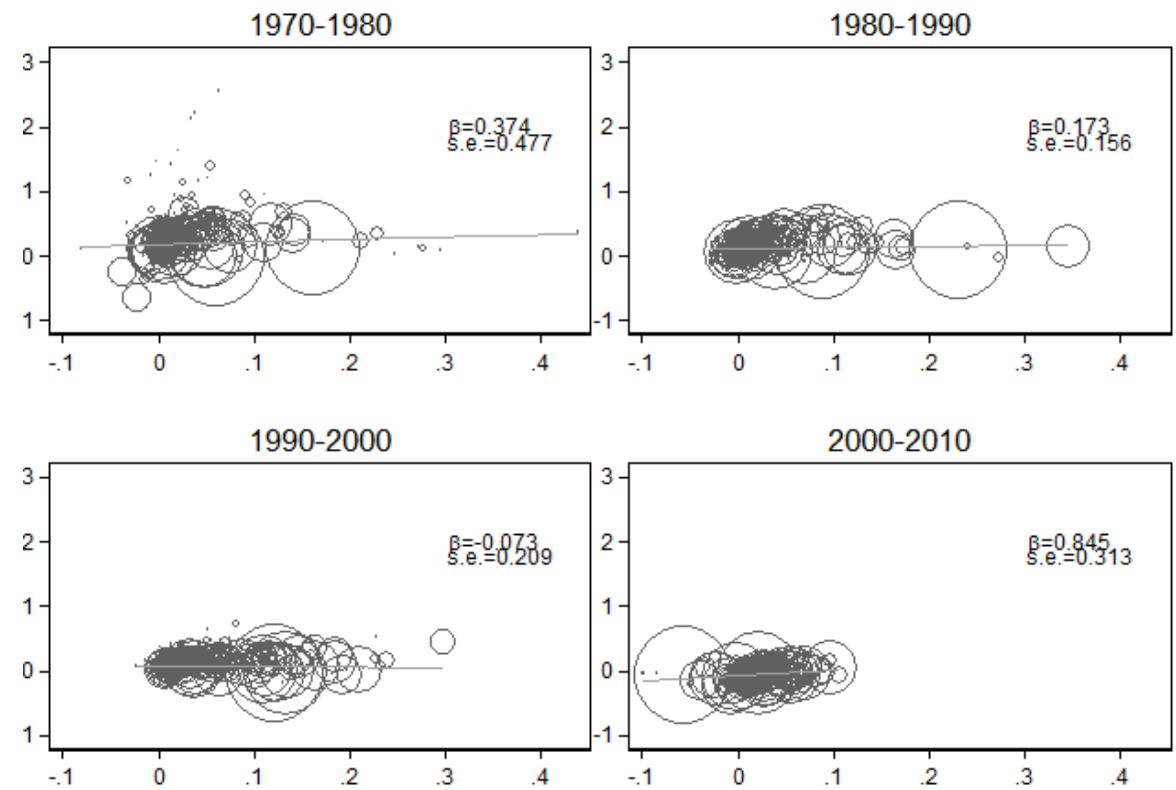

Note: Each panel shows the decade-changes in native employment relative to total employment at the beginning of the decade (vertical axis), and the decade-change in foreign-born as share of initial population. Unit of observation is a CZ in a decade. The size of the circle is proportional to the beginning of decade population in the CZ. 
Figure 7

Change in immigrants and change in weekly wages of non-college educated natives Commuting Zones per decade, pooled 1970-2010

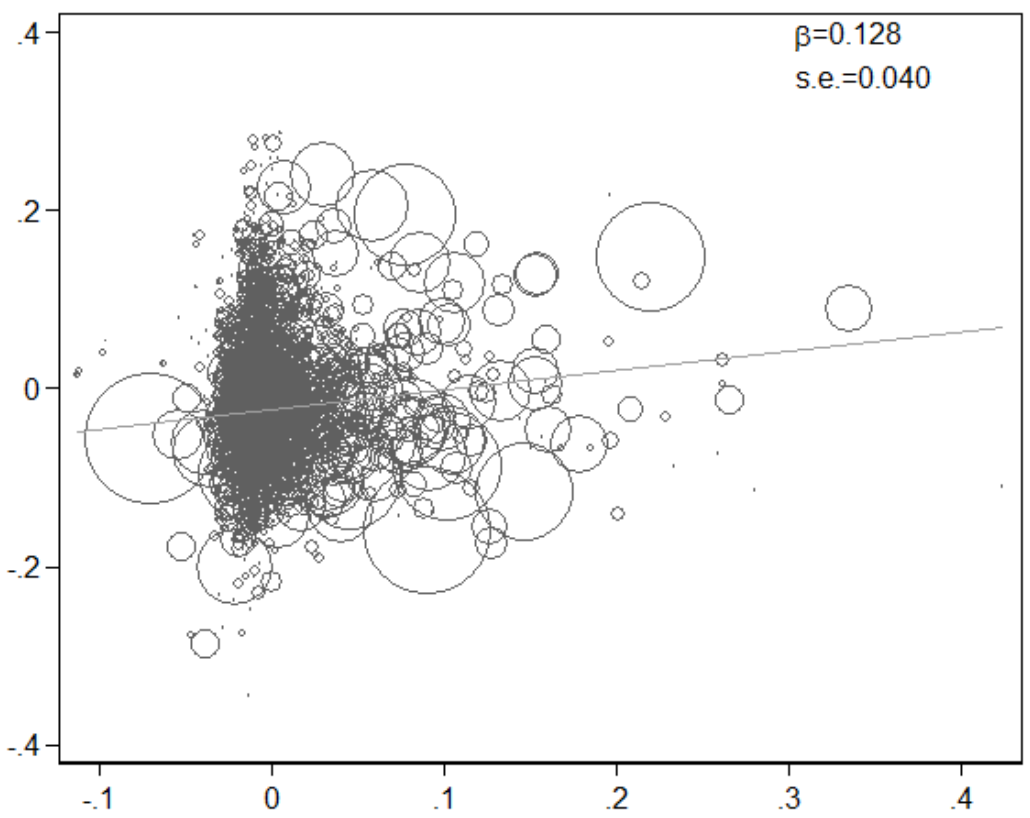

Note: The vertical axis shows the change in logarithmic weekly wages for non-college educated natives, the horizontal axis shows the change in foreign-born as share of initial population. Unit of observation is a CZ in a decade. The changes are cleaned from the decade average. The size of the circle is proportional to the beginning of decade population in the CZ.

Figure 8

Change in immigrants and change in weekly wages of college educated natives Commuting Zones per decade, pooled 1970-2010

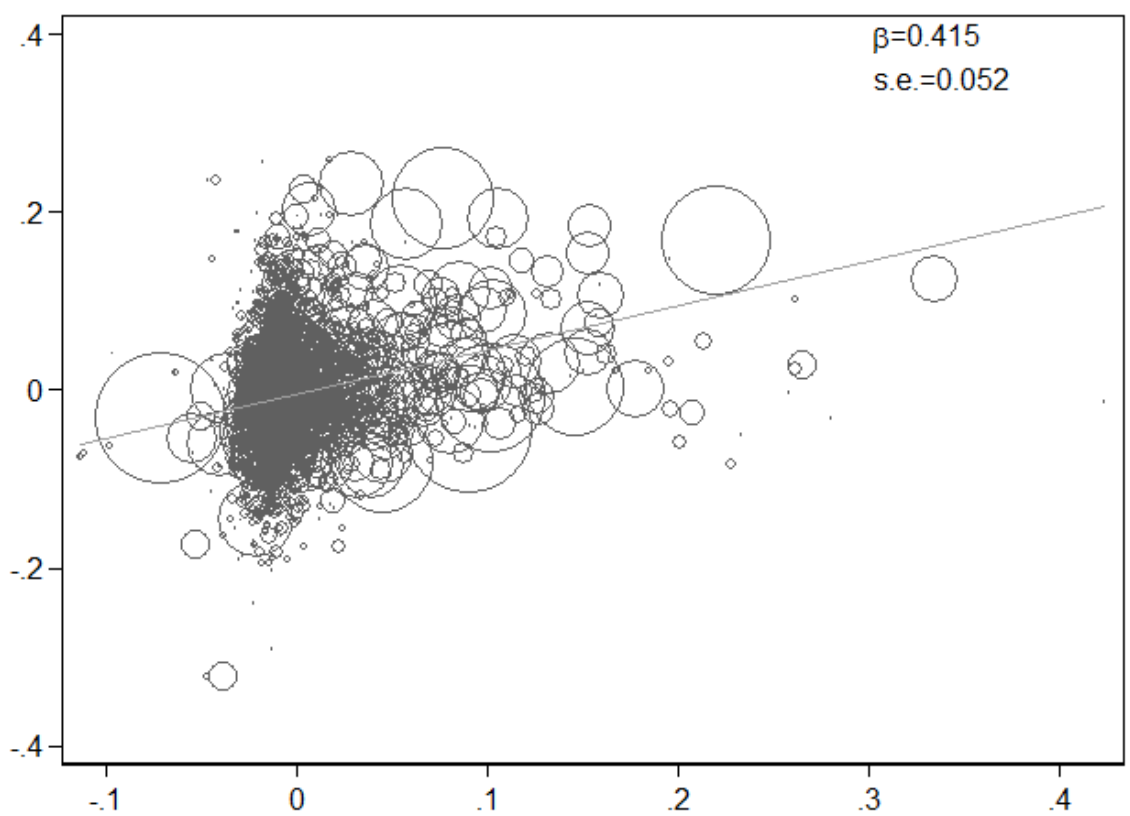

Note: The vertical axis shows the change in logarithmic weekly wages for natives with some college education or more, the horizontal axis shows the change in foreign-born as share of initial population. Unit of observation is a CZ in a decade. The changes are cleaned from the decade average. The size of the circle is proportional to the beginning of decade population in the CZ. 
Table 1

Correlation between change in immigrants and native log weekly wage change Aggregate area regressions, period 1970-2010

\begin{tabular}{lcll}
\hline \multicolumn{4}{l}{ Dependent variable: decade change of average native log weekly wage } \\
\hline Specification & $\mathbf{( 1 )}$ & $\mathbf{1}$ & $\mathbf{( 3 )}$ \\
& Commuting Zones & States & Census regions \\
\hline (1) FE: Decade & $0.34^{* *}$ & $0.29^{* *}$ & 0.27 \\
& $(0.06)$ & $(0.08)$ & $(0.24)$ \\
\hline (2) FE: Decade, Area & $0.36^{* *}$ & $0.54^{* *}$ & 0.38 \\
& $(0.04)$ & $(0.13)$ & $(0.21)$ \\
\hline (3): As (2) Dropping 1970-80 & $0.39^{* *}$ & $0.60^{* *}$ & 0.49 \\
& $(0.06)$ & $(0.17)$ & $(0.23)$ \\
\hline (4): Only 2000-2010 & $0.32^{* *}$ & 0.34 & 0.94 \\
& $(0.14)$ & $(0.31)$ & $0.55)$ \\
\hline (5): As (2) & $0.36^{* *}$ & $0.53^{* *}$ & 0.38 \\
Trimming bottom 10\% in size & $(0.04)$ & $0.13)$ & $0.22)$ \\
\hline (6): As (2) & 0.30 & $0.64^{* *}$ & $1.35^{*}$ \\
Trimming top 10\% in size & $(0.16)$ & $0.46)$ & $(0.44)$ \\
\hline
\end{tabular}

Note: Each cell shows the coefficient on the variable "change of immigrants as share of initial population" from a different regression of the type of Equation (1) in the text. The units of observations are geographical areas, as specified at the top of the column by decades. Variables are in decadal changes with change in native average log weekly wage as dependent variable and the change in immigrant population as share of initial population as explanatory variable. Regressions are weighted by the total number of individuals in the area at the beginning of the decade. Standard errors clustered at the area unit level.

$*, * *=$ significant at $5 \%, 1 \%$ confidence level 
Table 2

Correlation between change in immigrants and native employment change

Aggregate area regressions, period 1970-2010

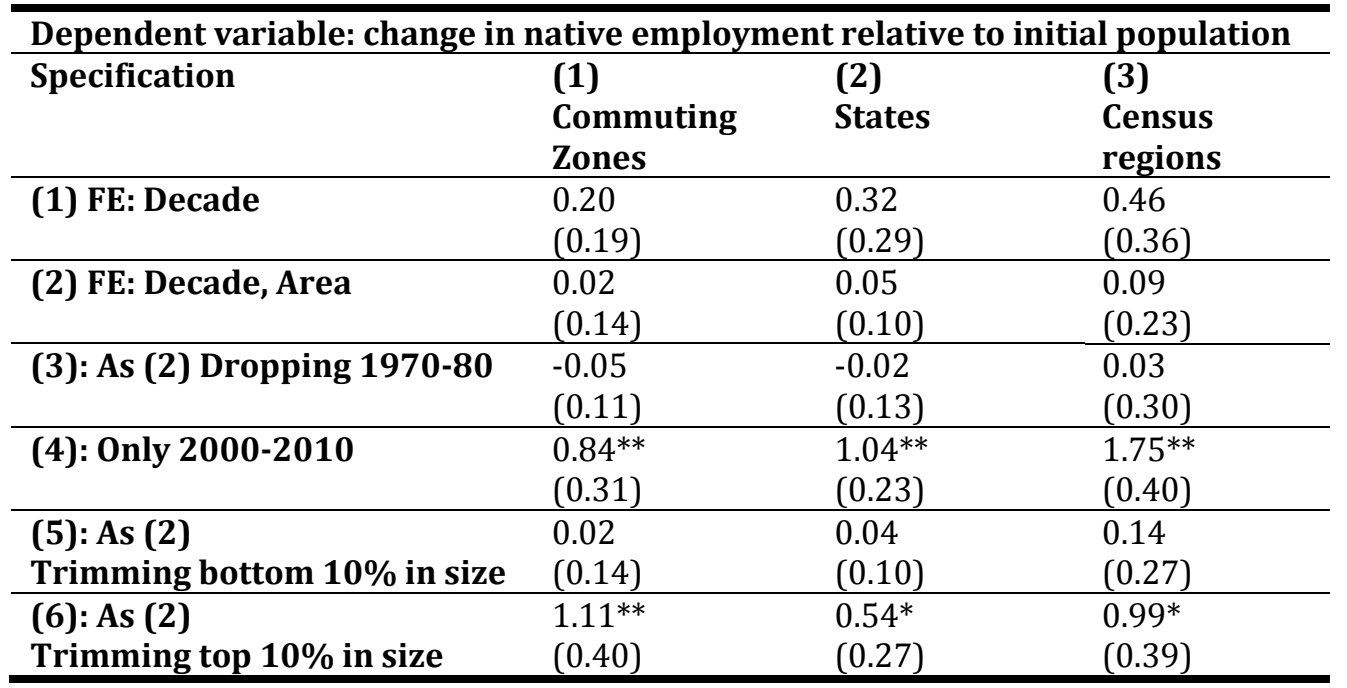

Note: Each cell shows the coefficient on the variable "change of immigrants as share of initial population" from a different regression of the type of Equation (1) in the text. The units of observations are geographical areas, as specified at the top of the column. Variables are in decadal changes with change in native employment as share of initial population as dependent variable and the change in immigrant population as share of initial population as explanatory variable. Regressions are weighted by the total number of individuals in the area at the beginning of the decade. Standard errors clustered at the regional unit level.

$*^{* *}=$ significant at $5 \%, 1 \%$ confidence level 
Table 3

Correlation between change in immigrants and native log weekly wage change Partial area-skill regressions, period 1970-2010

\begin{tabular}{llll}
\hline \multicolumn{3}{l}{ Dependent variable: decade change of average native log weekly wage } \\
\hline Specification & $\mathbf{( 1 )}$ & $\mathbf{( 2 )}$ & $\mathbf{( 3 )}$ \\
& $\begin{array}{l}\text { Commuting } \\
\text { Zones x skills }\end{array}$ & States x skills & $\begin{array}{l}\text { Census regions } \mathbf{x} \\
\text { skills }\end{array}$ \\
\hline (1) FE: Area, Skill, Decade. & $0.17^{* *}$ & 0.04 & -0.03 \\
& $(0.02)$ & $(0.02)$ & $(0.07)$ \\
\hline (2) FE: Area-Skill, Decade & $0.18^{* *}$ & 0.05 & -0.03 \\
& $(0.02)$ & $(0.04)$ & $(0.09)$ \\
\hline (3) FE: Area-Skill, Skill-Decade & $0.24^{* *}$ & $0.18^{* *}$ & 0.14 \\
& $(0.03)$ & $(0.05)$ & $0.12)$ \\
\hline (4) FE: Area-Skill, Skill-Decade, & $0.05^{*}$ & 0.04 & 0.01 \\
Area-Decade & $(0.02)$ & $(0.03)$ & $(0.08)$ \\
\hline (5): As (3) dropping 1970-80 & $0.28^{* *}$ & $0.24^{* *}$ & 0.25 \\
& $(0.04)$ & $(0.07)$ & $(0.17)$ \\
\hline
\end{tabular}

Note: Each cell shows the coefficient on the variable "change of immigrants as share of initial population" from a different regression. The units of observations are cells at the geographical areas by skill, as specified at the top of the column. Skills are four education by two experience group as defined in the text. Variables are in decade changes with change in native average log weekly wage as dependent variable and the change in immigrant population as share of initial population as explanatory variable. Regressions are weighted by the total number of individuals in the cell (defined as area x skill group) at the beginning of the decade. Standard errors clustered at the area level.

$*$, $* *=$ significant at $5 \%, 1 \%$ confidence level 
Table 4

Correlation between change in immigrants and native employment change

Partial area-skill regressions, period 1970-2010

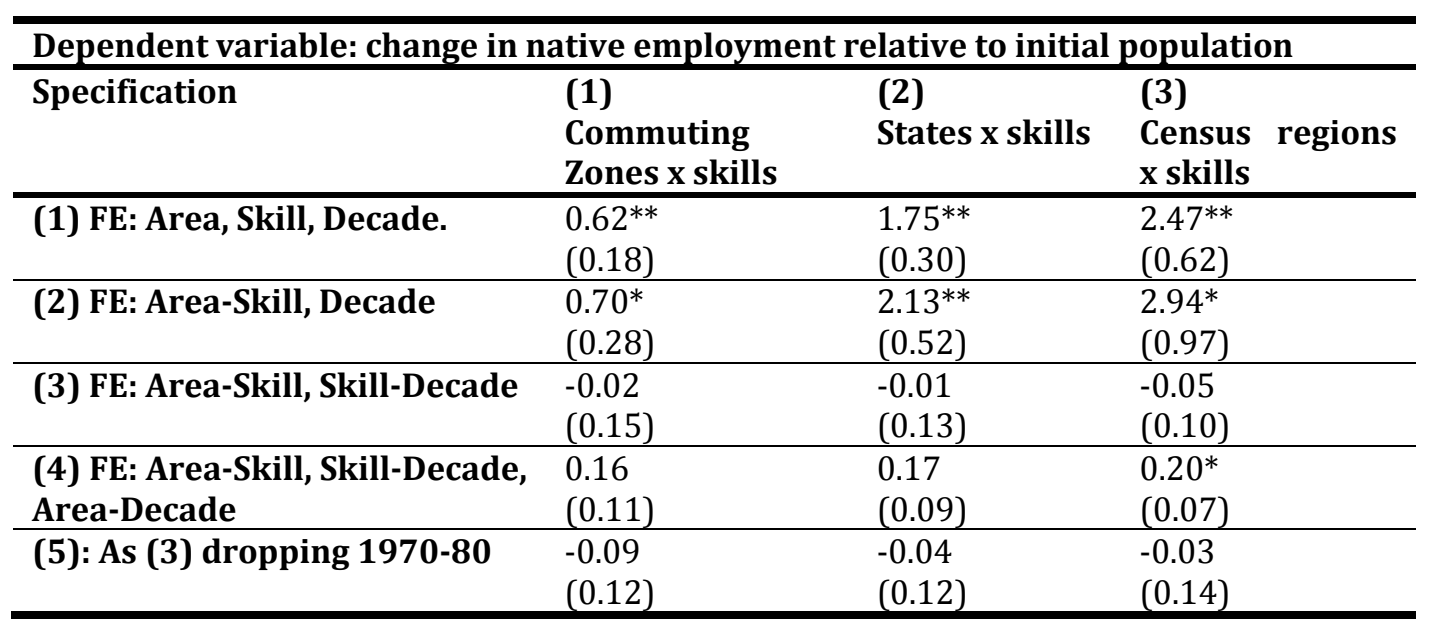

Note: Each cell shows the coefficient on the variable "change of immigrants as share of initial population" from a different regression. The units of observations are cells at the geographical areas by skill, as specified at the top of the column. Skills are four education by two experience group as defined in the text. Variables are in decade changes with change in in native employment as share of the initial total population as dependent variable and the change in immigrant population as share of initial population as explanatory variable. Regressions are weighted by the total number of individuals in the cell (defined as area x skill group) at the beginning of the decade. Standard errors clustered at the area level.

${ }^{*},{ }^{* *}=$ significant at $5 \%, 1 \%$ confidence level 
Table 5

Correlation between change in immigrants and native log weekly wages, schooling groups Aggregate area regressions, period 1970-2010

\section{Dependent variable: decade change of average native log weekly wage}

Specification

(1)

(2)

(3)

Commuting Zones States Census regions

HIGH SCHOOL OR LESS

\begin{tabular}{llll}
\hline (1) FE: Decade & $0.13^{* *}$ & 0.12 & 0.11 \\
& $(0.04)$ & $(0.11)$ & $(0.30)$ \\
\hline (2) FE: Decade, Area & $0.23^{* *}$ & $0.33^{* *}$ & 0.14 \\
& $(0.04)$ & $(0.14)$ & $(0.30)$ \\
\hline (3) Only 2000-2010 & 0.16 & 0.50 & 1.28 \\
& $(0.12)$ & $(0.31)$ & $(0.72)$ \\
\hline \multirow{2}{*}{ COLLEGE OR MORE } & & & \\
\hline (4) FE: Decade & & & \\
& $0.41^{* *}$ & $0.41^{* *}$ & $0.46^{* *}$ \\
(5) FE: Decade, Area & $(0.05)$ & $(0.05)$ & $0.14)$ \\
& $0.42^{* *}$ & $0.65^{* *}$ & $0.60^{* *}$ \\
& $(0.05)$ & $0.12)$ & $0.15)$ \\
\hline (6) Only 2000-2010 & 0.29 & 0.32 & 0.84 \\
& $(0.15)$ & $0.31)$ & $(0.56)$ \\
\hline
\end{tabular}

Note: Each cell shows the coefficient on the variable "change of immigrants as share of initial population" from a different regression of the type of Equation (1) in the text. The units of observations are geographical areas, as specified at the top of the column by decades. Variables are in decadal changes. In the upper part of the table labelled "HIGH SCHOOL OR LESS" the dependent variable is the change in native average log weekly wage for natives with a high school degree or less. In the lower part of the table labelled "COLLEGE OR MORE" the dependent variable is the change in native average log weekly wage for natives with some college education or more. Regressions are weighted by the total number of individuals in the area at the beginning of the decade. Standard errors clustered at the area unit level.

$*^{* * *}=$ significant at $5 \%, 1 \%$ confidence level 
Table 6

Immigration and native wages, including "Bartik" controls for change in labor demand Aggregate area regressions, Commuting Zones period 1970-2010

\begin{tabular}{lllll}
\hline \multicolumn{4}{l}{ Dependent variable: decade change of average native log weekly wage , CZ level } & \\
\hline Specification, & $\begin{array}{l}\text { (1) } \\
\text { All native workers }\end{array}$ & $\begin{array}{l}\text { (2) } \\
\text { Native high school or } \\
\text { less }\end{array}$ & $\begin{array}{l}\text { (3) } \\
\text { Natives } \\
\text { more }\end{array}$ & college or \\
\hline (1) FE: Decade & $0.28^{* *}$ & $0.07^{* *}$ & $0.36^{* *}$ \\
Coefficient on $\Delta$ (Immi) & $(0.04)$ & $(0.03)$ & $(0.04)$ & \\
\hline Coefficient on $\Delta$ (Bartik) & $2.74^{* *}$ & $2.65^{* *}$ & $2.30^{* *}$ \\
& $(0.29)$ & $(0.40)$ & $(0.26)$ \\
& & & \\
\hline (2) FE: Decade, Area & $0.34^{* *}$ & $0.20^{* *}$ & $0.40^{* *}$ \\
Coefficient on $\Delta$ (Immi) & $(0.06)$ & $(0.06)$ & $(0.05)$ \\
\hline Coefficient on $\Delta$ (Bartik) & $2.52^{* *}$ & $2.49^{* *}$ & $2.16^{* *}$ \\
& $(0.41)$ & $(0.56)$ & $(0.36)$ \\
\hline
\end{tabular}

Note: The units of observations are Commuting Zones. Variables are in decadal changes. In the first column the dependent variable is the change in native average log weekly wage for all natives. In the second column the dependent variable is the change in native average log weekly wage for native workers with a high school degree or less. In the third column the dependent variable is the change in native average log weekly wage for natives with some college education or more. The explanatory variables and specification are described in the first column. Regressions are weighted by the total number of individuals in the area at the beginning of the decade. Standard errors clustered at the area unit level.

${ }^{*},{ }^{* *}=$ significant at $5 \%, 1 \%$ confidence level 
Table 7

Immigration and native wages, using immigrant network instruments Aggregate area regressions, period 1980-2010 (row (1)), 1990-2010 (row (2)),

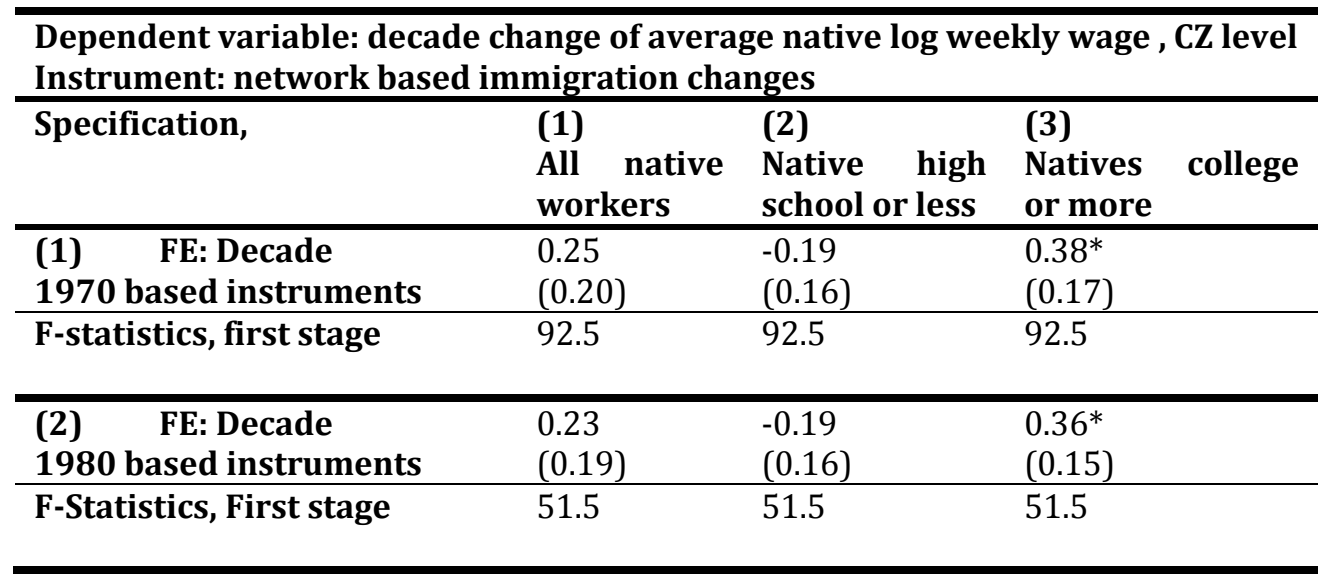

Note: The units of observations are Commuting Zones. Variables are in decadal changes. In the first column the dependent variable is the change in native average log weekly wage for all natives. In the second column the dependent variable is the change in native average log weekly wage for native workers with a high school degree or less. In the third column the dependent variable is the change in native average log weekly wage for natives with some college education or more. The specification and IV are described in the first column. The method of estimation in each specification is 2SLS using the shift-share instruments as described in the text, either using 1970 or 1980 as base year. Regressions are weighted by the total number of individuals in the area. Standard errors clustered at the area unit level.

$*, * *=$ significant at $5 \%, 1 \%$ confidence level 